\title{
Management of Blood in Milk Condition in Postpartum Dairy Cow
}

\author{
K. Saranya* \\ Valapady Milk Procurement Team, Salem and Namkkal District Cooperative Milk Producers \\ Union Ltd, Salem-636115, Tamil Nadu, India \\ *Corresponding author
}

\section{A B S T R A C T}

\begin{tabular}{|l|}
\hline K e y w o r d s \\
Blood in milk, \\
Postpartum dairy \\
cows, Homeopathy, \\
Allopathy
\end{tabular}

\section{Introduction}

Blood in milk after parturition is common in cows but the successful treatment is reported. In dairy cows, blood in milk occur from 2 to 8 days after parturition (Radositis et al., 1994) economic loss is collectively more and may precipitate mastitis. Blood in milk is usually diagnosed on the basis of clinical signs. Perform blood platelet count in cases which do not respond to conventional treatment as thrombocytopenia is one of the causes of blood in milk (George et al., 2008). Trauma to udder and teat is one of the common causes of blood in milk. Bacteria (Leptospira spp, Brevibacterium erythrogenes, Serratia marcescens, Micrococcus cerasinus,
Micrococcus chromidrogenes rubber, Micrococcus roseus, Lactorube faciens gruber, Sarcina rubra etc.), some viruses and red yeast (Monascus purpureus) may cause systemic infections associated with intravascular hemolysis and capillary damage in udder leading to reddish or pinkish discoloration of milk (Balhara et al., 2016).

Leptospirosis is one of the common causes of blood in milk in dairy animals. When leptospirosis is the cause of bloody milk, the milk from all 4 teat would be red in colour, thick in consistency and it contains blood clots and milk clots (Champawat et al., 1984.). Cattle affected with diseases characterized by low platelet count may show 
reddish or pinkish discoloration of milk due to leakage of blood into milk (George et al., 2008).

\section{Case History and Treatment}

A HF cross bred cow about 5 years old, calved 2 days back with the history of blood in milk from all the four teats for the past 2 days. Respiration rate, Temperature, Heart Rate and other physical parameter were normal.

The cow treated with progesterone $1500 \mathrm{mg}$ (Hyprogen plus-Vets pharma) I/M, 2ml of Etamsylate mixed with $1 \mathrm{ml}$ of Distilled water and it was given by intramammary route twice daily for 2-3 days. Fresh paste of $200 \mathrm{gms}$ of curry leaves mixed with 10 normal sized lemon twice daily for 3- 4 days.

\section{Results and Discussion}

The treated cow showed complete recovery in $4^{\text {th }}$ day onwards. Usually elevated level of progesterone maintains much of pregnancy and its secretion stops 30-40 hrs before parturition. Simultaneously sudden estrogen release at high level enhances the parturition by increasing uterine contractility and Milk secretion (Smith., 2008). The estrogen surge during parturition causes rupture of mammary gland capillaries, which causes blood in milk. Etamsylate is an effective medicine to prevent or stop bleeding from small blood vessels or capillaries. Curry leaf was traditionally used in ayurvedic medicine against intestinal bleeding in human (Irfan alikhan et al., 2005). Curry leaf exerts the styptic action on lactating mammary cells of cattle and the increased Vit-C content of lemon might have enhanced the styptic action (Umadevi and Umakanthan, 2016).

\section{References}

1. Balhara, A.K., N. Rana, S.K. Phulia, and Suneshy. 2016. Blood in milk -causes and control. Accessed at www.buffalopedia.cirb.res.in/

2. Champawat, S.S., P.M. Dholakia, V.M. Jhala, and H.A. Rajput, 1984. Blood in milk. Indian Vet. J., 61: 421-423.

3. George, L.W., T. J. Divers, N. Ducharme, and F. L. Welcome, 2008. Diseases of the teats and udder. In: Rebhun's Diseases of Dairy Cattle. 2nd Ed. Divers, T.J., and S.F. Peek (eds.). Saunders-Elsevier Publishers, St. Louis, USA. P: 335.

4. Irfan alikhan and Atiya khanum (2005). Medicinal and Aromatic plants of India, Ukaaz Publication, Hyderabad, Foirst edition, P: 233

5. Rodositis, O.M, Blood, D.C and Gay, C.C(1994). Veterinary Medicine, ELBS, $8^{\text {th }}$ edition, Tindall, UK, P: 614

6. Smith Bradford P (2008). Large animal internal medicine, $4^{\text {th }}$ edition, Mosby Elsevier.p.1142

\section{How to cite this article:}

Saranya, K. 2019. Management of Blood in Milk condition in Postpartum Dairy Cow. Int.J.Curr.Microbiol.App.Sci. 8(04): 2622-2623. doi: https://doi.org/10.20546/ijcmas.2019.804.305 